\title{
Prevention and Treatment of Recurrent Hepatitis B after Liver Transplantation
}

\author{
Rakhi Maiwall and Manoj Kumar* \\ Hepatology and Liver Transplantation, Institute of Liver and Biliary Sciences, New Delhi, India
}

\begin{abstract}
Chronic hepatitis B is a global health problem that leads to development of various complications, such as cirrhosis, liver cancer, and liver failure requiring liver transplantation. The recurrence of hepatitis B virus (HBV) post-liver transplantation is a major cause of allograft dysfunction, cirrhosis of the allograft, and graft failure. Patients with high viral load at the time of transplantation, hepatitis $\mathrm{B}$ e antigen (HBeAg) positivity, or those with a history of anti-viral drug resistance are considered as high-risk for recurrent HBV post-liver transplantation, while patients with low viral load, including HBeAg negative status, acute liver failure, and hepatitis D virus (HDV) co-infection are considered to be at low-risk for recurrent HBV post-liver transplantation. Antivirals for patients awaiting liver transplantation(LT) cause suppression of HBV replication and reduce the risk of recurrent HBV infection of the allograft and, therefore, all HBV patients with decompensated cirrhosis should be treated with potent antivirals with high genetic barrier to resistance (entecavir or tenofovir) prior to liver transplantation. Prevention of post-liver transplantation recurrence should be done using a combination of hepatitis B immunoglobulin (HBIG) and antivirals in patients at high risk of recurrence. Low dose HBIG, HBIG-free protocols, and monoprophylaxis with high potency antivirals can still be considered in patients at low risk of recurrence. Even, marginal grafts from anti-HBc positive donors can be safely used in hepatitis $B$ surface antigen (HBsAg) negative, preferably in anti-hepatitis B core $(\mathrm{HBC})$ /anti-hepatitis B surface (HBs) positive recipients. In this article, we aim to review the mechanisms and risk factors of HBV recurrence post-LT in addition to the various
\end{abstract}

Keywords: Hepatitis B; Recurrent; Liver transplant.

Abbreviations: ADV, adefovir; AGL, antigenic loop; APASL, Asia Pacific Association for the Study of Liver; cccDNA, covalently closed circular DNA; CHB, chronic hepatitis $B$; CI, confidence interval; CTLA-4, Cytotoxic T-lymphocyte-associated protein 4; DNA, deoxyribonucleic acid; ETV, entecavir; $\mathrm{HBC}$, hepatitis $\mathrm{B}$ core; $\mathrm{HBeAg}$, hepatitis $\mathrm{B}$ e antigen; HBIG, hepatitis B immunoglobulin; HBs, hepatitis $B$ surface; HBsAg, hepatitis B surface antigen; HBV, Hepatitis B virus; HCC, hepatocellular carcinoma; HDV, Hepatitis D virus; HIV, human immunodeficiency virus; HLA, human leukocyte antigen; IFN- $\gamma$, interferon gamma; IM, intramuscular; IV, intravenous; LAM, lamivudine; LT, liver transplantation; MPL, monophosphoryl lipid; NAs, nucleos(t)ide analogues; NTCP, sodium taurocholateco transporting polypeptide; OLT, orthotopic liver transplantation; PD1, program death receptor 1 ; RR, response rate; SC, subcutaneous; TDF, tenofovir; TIM3, T-cell immunoglobulin and mucin-domain containing-3.

Received: 04 November 2015; Revised: 01 February 2016; Accepted: 01 February 2016

DOI: $10.14218 /$ JCTH.2015.00041.

*Correspondence to: Manoj Kumar, Department of Hepatology and Liver Transplantation, Institute of Liver and Biliary Sciences, D1 Vasant Kunj, New Delhi, India. Tel: +91-11-4630000, Fax: +91-11-26123504, E-mail: manojkumardm@gmail. com treatment strategies proposed for the prevention of recurrent HBV infection

(C) 2016 The Second Affiliated Hospital of Chongqing Medical University. Published by XIA \& HE Publishing Inc. All rights reserved.

\section{Introduction}

Hepatitis B virus (HBV) infection is a global health problem and is known to be endemic in the Eastern world. An estimated 240 million people are chronically infected with hepatitis $B$ (defined as hepatitis $B$ surface antigen (HBsAg) positive for at least 6 months) and more than 780,000 people die every year due to complications of hepatitis $B$, including cirrhosis and liver cancer. ${ }^{1,2}$ Chronic infection with HBV results in the development of cirrhosis, liver cancer, and liver failure, necessitating liver transplantation (LT). During the early years of LT in the absence of antiviral prophylaxis, the recurrence of HBV post-liver transplantation was almost universal. Recurrent infection was known to cause allograft dysfunction, cirrhosis of the allograft, and graft failure. ${ }^{2}$ The introduction of intravenous (IV) hepatitis B immunoglobulin (HBIG) in the early 1990 s was a major breakthrough in the prevention of postLT recurrence of hepatitis $B$. In the current era, more than $90 \%$ of recurrent HBV infections can be clinically controlled by treatment with antivirals i.e., nucleos(t)ide analogues (NAs) in combination with HBIG. The use of newer potent antiviral drugs with high genetic barrier to resistance [e.g., entecavir (ETV) or tenofovir (TDF)] has further led to significant improvements in the outcome of patients both pre- and postliver transplantation. Recent data with these drugs has suggested that a lower dose of HBIG or even HBIG-free protocols could effectively prevent post-liver transplantation recurrence. ${ }^{3}$ This article details the mechanisms and risk factors of HBV recurrence post-LT and summarizes various treatment strategies proposed for the prevention of recurrent HBV infection.

\section{Immune system in the pathogenesis of HBV}

The immune system is inherently capable of clearing more than $90 \%$ of HBV infections acquired during adulthood. ${ }^{4}$ Induction of a robust T-cell response accompanied by an increase in the production of interferon gamma (IFN- $\gamma$ ), activation of natural killer cells, and CD8+ T-cell mediated clearance of infected hepatocytes is responsible for acute self-limiting HBV infection. ${ }^{5}$ However, in patients who develop chronic HBV infection, a weak and transient virusspecific $\mathrm{T}$-cell response caused by an excess of inhibitory 
signals, i.e.,cytotoxic T-lymphocyte-associated protein 4 (CTLA-4), ${ }^{6}$ pro-gram death receptor 1 (PD1), ${ }^{7}$ T-cell immunoglobulin, and mucin-domain containing-3 (TIM3), is predominant. In addition to this, a decrease in the function of regulatory $T$ cells and dendritic cells as well as an unabated activation of natural killer cells is responsible for hepatocyte injury in chronic HBV. ${ }^{8}$ Recent studies have also identified dense non-antigen specific T-cell infiltration as a cause of hepatocyte damage in patients with chronic HBV infection. ${ }^{4}$ In post-LT patients, both $B$ and $T$-cell mediated adaptive immune response are needed to control the recurrence of infection. Combination treatment with HBIG and NAsis known to mask the adaptive immune response in these patients. ${ }^{4,9}$ Further, the response to therapeutic vaccines is also determined by the adaptive immune response to the virus.

Mechanisms, diagnosis, riskfactors, and consequences of $\mathrm{HBV}$ recurrence after LT

\section{Mechanisms of $H B V$ recurrence after $L T$}

HBV is a small and enveloped deoxyribonucleic acid (DNA) virus containing a relaxed circular partially double-stranded DNA genome comprised of three surface proteins, i.e., large $(\mathrm{L})$, middle $(\mathrm{M})$, and small $(\mathrm{S})$ proteins. ${ }^{10,11}$ The $\mathrm{L}$ protein is required for the release and envelopment of mature virion, which is essential for viral entry. ${ }^{12}$ It comprises the PreS1 and Pres2 domains, while the M protein includes the PreS2 domain in the $\mathrm{N}$-terminus. ${ }^{10}$ The determinants of infectivity of the virus include the C-terminal of PreS1, the N-terminal of Pres2 protein, and the antigenic loop (AGL) of the $S$ domain. HBIG predominantly targets the AGL-domain of the virus. ${ }^{13,14}$ The various mechanisms by which HBIG prevents HBV transmission include binding to the circulating viral particles by immune complex formation, preventing infection of naïve hepatocytes by blocking the putative HBV receptor, and inhibiting secretion of HBsAg from the infected hepatocytes. ${ }^{15}$ NAs inhibit reverse transcription of pregenomic RNA, decreasing synthesis of HBV-DNA, but they do not clear covalently closed circular DNA (cccDNA). This is because the cccDNA episome is the transcriptional template for both HBV messenger RNA and pregenomic RNA. ${ }^{16}$ ccCDNA is known to persist in the nucleus of infected hepatocytes as a minichromosome and is responsible for viral persistence. ${ }^{17}$ Because of this, once infected, HBV stays in the infected hepatocytes for life, despite seroclearance of HBsAg and emergence of anti-HBs antibody. ${ }^{18}$ Measurable low levels of HBV DNA in the serum, liver, and peripheral blood mononuclear cells or the presence of ccCDNA in the liver tissue has been demonstrated in patients even in the absence of HBsAg. This is called occult HBV infection. ${ }^{19-23}$ This becomes of clinical relevance in the context of immunosuppression, which can resultin viral flare in patients with occult hepatitis $B$ in the absence of immunoprophylaxis.

Recent studies have identified sodium taurocholate cotran-sporting polypeptide (NTCP) as a high affinity receptor for HBV entry on the hepatocyte membrane. ${ }^{24}$ NTCP is known tospecifically interact with the PreS1 domain of HBV. The discovery of the NTCP receptor has not only led to unveiling of the mechanism of HBV entry into the hepatocytes but also is considered as an effective therapeutic target to prevent graft liver from HBV infection after orthotopic LT (OLT). ${ }^{25,26}$

Immunosuppression treatment post-LTis known to induce viral replication, even in HBsAg-negative, anti-HBs antibodypositive patients. ${ }^{27,28}$ Moreover, HBV itself evades the immune system, and HBV-specific CD4+ and CD8+ T-cell responses have been shown to correlate with viral and hepatitis control during acute and chronic infection. ${ }^{29-31}$ Normally, seroconversion of a person from HBsAg-positive to anti-HBs-antibody-positive is a marker for clinical cure and discontinuation of NAss. However, in the context of organ transplant, immunosuppression ${ }^{32}$ with steroids and calcineurin inhibitors is associated with recurrent hepatitis $B$ characterized by high amounts of HBV-DNA and severe lobular hepatitis with a high incidence of fatal liver failure in the absence of antiviral prophylaxis. ${ }^{33} \mathrm{HBV}$ reinfection in these patients is primarily a consequence of an immediate reinfection of the graft by circulating HBV particles or a later reinfection from HBV particles coming from extrahepatic sites, such as peripheral blood mononuclear cells, or both. Viral replication has in fact been reported to be maximal after glucocorticoids, which cause enhanced viral replication via direct stimulation of the glucocorticoid responsive enhancer region on the HBV genome. ${ }^{2,4}$ An early withdrawal of steroids has, therefore, been proposed to minimize the incidence of recurrence of $\mathrm{HBV}$ and is practiced at most centers, even though there are no large prospective studies that provide evidence in favor of this strategy. $2,34-36$

\section{Diagnosis and risk factors for $H B V$ recurrence after $L T$}

Recurrence of HBV infection after LT is defined as the reappearance of circulating $\mathrm{HBsAg}$ with or without detectable HBV DNA. However, only patients who develop persistently detectable HBV DNA were shown to be at risk for clinical disease and graft loss. ${ }^{37,38}$ Measurable low levels of HBV DNA in serum, liver, and peripheral blood mononuclear cells or the presence of total HBV DNA and ccCDNA in liver tissue could also be detected transiently after LT in the absence of a positive $\mathrm{HBsAg}$, irrespective of the type of prophylaxis used. ${ }^{19-22}$ The significance of these findings is unclear but suggests that occult HBV reinfection occurs in some HBV recipients after LT despite prophylaxis and implies a risk for overt HBV recurrence if the prophylaxis is discontinued.

Various risk factors have been identified for HBV recurrence post-LT. Patients with high viral load at the time of transplantation; HBeAg positivity; history of anti-viral drug resistance; hepatocellular carcinoma (HCC) at LT; HCC recurrence; or chemotherapy used for $\mathrm{HCC}$ are considered highrisk for recurrent HBV post-LT, while patients with low viral load (including HBeAg negative status), acute liver failure, and HDV co-infection are considered to be at low-risk for recurrent HBV post-LT. 2,35,37, 38

The correlation between the viral load at the time of LT and the risk of hepatitis $B$ recurrence was studied by Marzano and colleagues $^{38}$ in 177 patients with HBV related liver disease who underwent LT. There was a linear correlation between recurrence and viral load at the time of surgery; and in patients with HBV DNA higher than 100,000 copies/mL the recurrence rate was $50 \%$ higher $(p=0.003)$ than patients with a viral load of $200-99,999$ copies $/ \mathrm{mL}$, i.e., $7.5 \%$. The recurrence rate was $0 \%$ in patients with HBV DNA less than 200 copies/mL. ${ }^{38}$ Similar results were observed in a multicentric trial conducted in 17 European centers. In this study, 372 consecutive HBsAg-positive patients who underwent LT were studied for HBV recurrence post-LT. The actuarial risk of recurrence of $\mathrm{HBV}$ is $50 \%$. This risk was maximal for patients with HBV-related cirrhosis (67\%) and lowest for patients with fulminant hepatitis $B$, i.e., $17 \%$. Further, among patients with 
$\mathrm{HBV}$-related cirrhosis, the risk of HBV recurrence was highest $(83 \%)$ in those who were seropositive for HBV DNA at the time of transplantation and lowest $(58 \%)$ in those with neither HBV DNA nor HBeAg detectable in serum. The recurrence rates were also lower in patients given prolonged duration of passive prophylaxis with anti-HBs immune globulin. Independent predictors of lower risk of HBV recurrence were long-term administration of the immune globulin, hepatitis delta virus superinfection, and acute liver disease. Importantly, recurrence was also associated with poor survival in these patients. ${ }^{2}$ Considering a direct relationship between HBV viral load at transplantation (i.e., >105 copies $/ \mathrm{mL}$ ) and the rate of HBV recurrence, ${ }^{36}$ antivirals should be used before transplantation in all patients to achieve undetectable HBV DNA levels to reduce the risk of HBV recurrence. ${ }^{39}$ In addition, rapid and sustained suppression of HBV-DNA before transplant results in improved survival rates, i.e., $87 \%$, compared to $44 \%$ at 3 years in patients with untreated HBV infection. 39,40

Presence of HCC at LT, HCC recurrence, and chemotherapy used for HCC are also independently associated with an increased risk of HBV recurrence post-LT. This was demonstrated in a study of 99 patients of HBV related cirrhosis, of which 31 patients had HCC who underwent LT for cirrhosis. It was seen that the presence of HCC, a pre-LT DNA load more than 100,000 copies/mL, and HBIG monoprophylaxis were significant and independent predictors of HBV recurrence post-LT. Recurrence was significantly more frequent in patients with HCC at time of LT (35\% versus $4 \%$, $p<0.0001) .{ }^{35}$

Thus, patients who are considered high-risk for recurrent HBV post-LT include those with high viral load at the time of transplantation, $\mathrm{HBeAg}$ positivity, a history of antiviral drug resistance, presence of HCC at LT, HCC recurrence, or chemotherapy used for HCC, while patients with low viral load (including $\mathrm{HBeAg}$ negative status), acute liver failure, and HDV co-infection are considered to be at low-risk for recurrent HBV post-LT.

\section{Consequences of $H B V$ recurrence after $L T$}

Todo et al. ${ }^{41}$ found in patients with recurrent HBV infection post-OLT that the rate of hepatitis development in the graft was accelerated. Further, it was seen that beyond 2 months of transplant the mortality and rate of graft failure were significantly higher in the HBV-related group than in the non-HBV related group. Lerut et al. ${ }^{42}$ found the median time to reinfection was 145 days (range 15 to 2,615 days) and reported fibrosing cholestatic hepatitis in three of the $16 \mathrm{HBV}$ reinfected patients, all of whom died within 1 year post-OLT. Liver failure developed in two of these 16 patients, and they died within 2 years post-OLT. ${ }^{43}$ The presence of HDV co-infection and adequate immunoprophylaxis were the only significant prognostic variables in these patients. In another study evaluating the histopathological features in patients who underwent transplant for HBV related liver disease, acute cellular rejection was predominantly seen in the first 30 days of OLT, while beyond day 60 , acute or chronic hepatitis related to hepatitis $B$ was seen more frequently. Thereafter, a chronic carrier state or chronic active hepatitis and/or cirrhosis were the main features seen on biopsy. The histological findings of graft failure in these patients revealed heterogeneous states, such as massive necrosis, cirrhosis, chronic rejection, or hepatic artery thrombosis. The recurrence of HBV was not affected by the human leukocyte antigen (HLA) status of the donors, indicating that the viral epitope could be recognized via different HLA and T cell receptors. ${ }^{9,43}$

Taken together, these findings clearly show that reappearance of HBV in the grafted liver could occur early after OLT with serious consequences, necessitating the need for an adequate immunoprophylaxis. ${ }^{35,38}$

\section{Prevention of HBV Recurrence after LT}

Before the availability of effective antiviral and immuneprophylactic agents, high rates of hepatitis $B$ recurrence after LT for chronic hepatitis B (CHB)-related diseases were observed and were almost universal in those with detectable viremia at the time of transplant. Over the past 3 decades, there have been significant advances in both the treatment of $\mathrm{CHB}$ and prophylaxis against disease recurrence. Prophylaxis for HBV recurrence post-LT has evolved from using high dose IV HBIG long term to low dose IV/intramuscular (IM)/subcutaneous (SC) HBIG along with antivirals [mainly lamivudine (LAM) and adefovir (ADV)] to HBIG free regimens (either stopping HBIG after a finite duration after LT or no use of HBIG at all) with the availability of highly potent NAs (ETV and TDF).

\section{HBIG containing prophylaxis regimens}

Prior to the availability of effective HBV prophylaxis in the 1980 s, LT for CHB was a relative contraindication. High rates of graft re-infection led to severe flares, and loss of the graft occurred in the absence of antiviral therapy. HBIG is a polyclonal antibody to $\mathrm{HBsAg}$ that is derived from pooled human plasma HBIG, which consists of high-titer antibodies against the AGL domain of the HBsAg $L$ protein. ${ }^{44}$ The use of HBIG after LT was the first major milestone in the prevention of post-transplant HBV recurrence. HBIG monotherapy reduced HBV recurrence approximately by a rate of $70 \% .40$ Monoprophylaxis with high-dose of HBIG in the anhepatic phase, followed by daily and subsequent monthly administration at a fixed dose, was routinely considered prior to the availability of the NAs. ${ }^{45-47}$ However, the major limitation of such protocols was the high cost associated with HBIG as well as the inconvenience of administering IV injections at frequent intervals to transplanted patients for almost a year. ${ }^{38}$ Additional limitations included an unreliable supply of the formulation, the local and systemic side effects, and the risk of infection from HBV mutants that escaped neutralization. $2,37,38$

Further, with experience it became evident that recurrence is not only determined by the dose and duration of the HBIG therapy but also by trough surface antibody titres. 2,34,37,38

There are various studies that have assessed HBV recurrence based on the dose, duration, and route of HBIG therapy as well as target titres of anti-HBs. In conventional protocols, HBIG is used at a high dose (e.g., 10,000 IU/day) during the anhepatic phase and the first postoperative week to neutralize $\mathrm{HBsAg}$. In the early post-LT period, some studies reported that high IV HBIG dosage ( $\geq 10,000$ IU/day) versus low HBIG dosage ( $<10,000 \mathrm{IU} /$ day) was associated with a lower frequency of $\mathrm{HBV}$ recurrence. ${ }^{2}$ In the medium- and long-term follow-up, IV HBIG was administered in two different ways: at a frequency dictated by the maintenance of specific anti-HBs levels or on a fixed schedule. Although the latter approach is 
simpler and requires less monitoring, it is more expensive. ${ }^{48}$ The target levels for anti-HBs titers varied with time after LT: generally, anti-HBs levels were maintained $>500 \mathrm{IU} / \mathrm{L}$ during months $1-3,>250 \mathrm{IU} / \mathrm{L}$ until months $6-12$, and $>100 \mathrm{IU} / \mathrm{L}$ thereafter. Table 1 includes a summary of studies evaluating high dose HBIG for the prevention of post-LT HBV recurrence.

Considering the limitations of IV HBIG, alternative approaches of administering HBIG have also been studied. These strategies include the use of IM or SC preparations of HBIG, which are advantageous because of improved tolerability and the possibility of self-administration by patients at home. ${ }^{49}$

The success of using a low dose of IMHBIG (400-800 IU) in combination with LAM was shown by Gane and colleagues. The rate of HBV recurrence was shown to be as low as $1 \%$ at 1 year and $4 \%$ at 5 years in their study. ${ }^{44}$ Further, this efficacy was achieved at a reduced cost, which was less than $10 \%$ the cost of high dose IV HBIG regimens. ${ }^{44}$ Zheng et al. in a retrospective study evaluated 165 patients who received either low dose IM HBIG with LAM (114 patients) or LAM monotherapy (51 patients) post-LT. The low-dose HBIG protocol in their study involved administration of HBIG as 800 IU daily for 6 days, weekly for 3 weeks, and subsequently on a monthly basis. ${ }^{50}$ Again, a superior response rate was demonstrated with the combination treatment in preventing HBV recurrence as compared to LAM monotherapy ( $13.5 \%$ versus $27.4 \%$ at 1 year and $15.2 \%$ versus $39.7 \%$. at 2 years, respectively). Similar to these results, another study done in 183 patients receiving combination prophylaxis with antiviral therapy (mostly LAM monotherapy) with HBIG found no significant difference in recurrence rates between the different routes and dosages of HBIG therapy. HBIG in this study was given either as IV high-dose regimen (10,000 IU monthly), IV lowdose regimen (3,000-6,000 IU monthly), or as IM low-dose regimen (1,000-1,500 IU every $1-2$ months) for a finite duration (median duration 12 months). Multivariate analysis further showed that only positivity for $\mathrm{HBeAg}$ and high viral load at transplant, but not the post-transplant HBIG regimen, were associated with HBV recurrence. ${ }^{51}$ Interestingly, in all the studies evaluating low-dose IM HBIG, the recurrence rate was primarily affected by the level of viremia pre-LT. Therefore, the success of low-dose HBIG is more likely in patients with a lower level of HBV viremia pre-LT. ${ }^{52}$

The effectiveness and safety of self-administration of a SC regimen of HBIG was demonstrated by Costanzo et al. in a cohort of 135 LT patients who received a 48 week treatment of SC HBIG. The SC preparation was found to be effective in a majority of patients $(97.8 \%)$, wherein it was able to reach the target anti-HBs titers of more than $150 \mathrm{IU} / \mathrm{L} .{ }^{49}$

\section{Combination therapies of antivirals and HBIG}

The advent of antiviral therapy further changed the landscape of post-LT prophylaxis for HBV. Because of differences in the mechanisms of action of antivirals and HBIG, combination therapy has become the standard of care for the management of hepatitis B post-LT. ${ }^{53,54}$ The first trial of combination treatment with long-term HBIG with the first-generation NA, i.e., lamivudine (LAM), was conducted in 1998, which showed excellent 1-year survival rates with this therapy. ${ }^{21}$

Table 1. Studies on high dose hepatitis B immunoglobulin (HBIG) to prevent hepatitis B virus (HBV) recurrence post-liver transplantation (LT)

\begin{tabular}{|c|c|c|c|c|c|c|c|}
\hline Reference & $\begin{array}{l}\text { Number } \\
\text { of } \\
\text { patients }\end{array}$ & $\begin{array}{l}\text { Anti-viral } \\
\text { pre-LT } \\
{[\%]}\end{array}$ & $\begin{array}{l}\text { DNA at LT } \\
{[\mathrm{IU} / \mathrm{mL}]}\end{array}$ & HBIG protocol & $\begin{array}{l}\text { Follow up } \\
\text { [months] }\end{array}$ & $\begin{array}{l}\text { Recurrence } \\
{[\%]}\end{array}$ & Antivirals \\
\hline Markowitz et al. ${ }^{46}$ & 14 & 36 & 7 & $\begin{array}{l}100,000 \mathrm{IU} \text { for } 1 \\
\text { month then } \\
10,000 \mathrm{IU} / \text { month }\end{array}$ & 12.7 & 0 & \\
\hline Han et al. ${ }^{47}$ & 59 & 34 & 27 & $\begin{array}{l}80,000 \text { IU in } 1^{\text {st }} \\
\text { month; then } 10,000 \\
\text { IU/month }\end{array}$ & 15 & 0 & \\
\hline Marzano et al. 38 & 26 & 100 & 27 & $\begin{array}{l}46,500 \text { IU first } \\
\text { month; then } 5000 \\
\text { IU/month }\end{array}$ & 30 & 4 & \\
\hline Rosenau et al. ${ }^{22}$ & 21 & 52 & 24 & $\begin{array}{l}40,000 \text { IU } 1 \text { stwk; } \\
\text { aim for titer }> \\
500 \text { IU/L for } 1 \text { week } \\
\text { and then }>100 \text { IU/L }\end{array}$ & 21 & 10 & $\begin{array}{l}\text { Lamivudine } \\
\text { - resistant } \\
\text { pre-LT }\end{array}$ \\
\hline Rosenau et al. ${ }^{40}$ & 19 & 100 & 47 & $\begin{array}{l}10,000 \mathrm{IU} / \text { day until } \\
\text { titer > } 1000 \mathrm{IU} / \mathrm{L} ; \\
\text { then aim for titer } \\
>100 \mathrm{IU} / \mathrm{L}\end{array}$ & - & 20 & $\begin{array}{l}\text { Lamivudine } \\
\text { - resistant } \\
\text { pre-LT }\end{array}$ \\
\hline Seehofer et al. ${ }^{103}$ & 17 & 100 & 29 & $\begin{array}{l}80,000 \text { IU for } 1 \\
\text { month; then aim for } \\
\text { titer }>100 \mathrm{IU} / \mathrm{L}\end{array}$ & 25 & 18 & $\begin{array}{l}\text { Lamivudine } \\
\text { - resistant } \\
\text { pre-LT }\end{array}$ \\
\hline Steinmuller et al. ${ }^{104}$ & 51 & 100 & - & $\begin{array}{l}10,000 \text { IU/day until } \\
\text { sAg cleared; then } \\
\text { aim for titer > } 100 \\
\text { IU/L }\end{array}$ & 35 & 8 & $\begin{array}{l}\text { ( } 3 \text { out of } 4 \\
\text { lamivudine } \\
\text { resistant } \\
\text { pre-LT) }\end{array}$ \\
\hline
\end{tabular}


Subsequent reports also described successful control of HBV recurrence with this combination. The major advantage of combin-ation therapy was the reduction in the dose of HBIG and, therefore, the cost of the immunoprophylaxis. The independent and synergistic effects of the combination of HBIG and LAM reduced HBV recurrence to less than $5 \%$ at 1 year of follow-up. ${ }^{55}$ Data from a meta-analysis comparing HBIG to combination treatment (including nine studies comparing antivirals to combination treatment and three comparing LAM to $\mathrm{HBIG}$ ) showed that post-transplant prophylaxis against HBV with combination HBIG and LAM was superior to either agent alone and improved survival compared to HIBG alone. Combination treatment reduced $\mathrm{HBsAg}$ reappearance (response rate (RR) 0.28 ; 95\% confidence interval (CI) $0.12-0.66)$ and was significantly better than antivirals in preventing reappearance of HBsAg (RR 0.31 ; 95\% CI $0.22-$ 0.44 ), even when low-dose HBIG was given. However, even in combination treatment, the efficacy of HBIG combined with ADV was noted to be superior to that of HBIG combined with LAM. ${ }^{45}$ The superiority of ADV over LAM was also well demonstrated in a systematic review of 46 studies, including 2,162 HBV patients who underwent LT, wherein it was found that patients who received HBIG and LAM experienced HBV recurrence more frequently than patients receiving HBIG and ADV with or without LAM [6.1\% versus $2.0 \% ; p=0.024]$. Contrary to the combination of HBIG and LAM, where the dose of HBIG determined HBV recurrence, combination of HBIG and ADV was not affected by HBIG dosage, indicating that the dose of HBIG may not be important when used in combination with more potent antivirals. ${ }^{52}$

\section{HBIG-free prophylactic regimens}

Various strategies for HBIG-free therapy have been studied, including withdrawal of HBIG after a finite period, use of newer potent antiviral agents [ETV or TDF] with HBIG for short periods or without HBIG at all, and active immunization with HBV vaccines. ${ }^{9}$

HBIG free protocols were initially studied with LAM. Monotherapy with LAM showed a $10 \%$ recurrence rate at 1 year, which was increased to $22-41 \%$ at 3 years due to the emergence of escape mutations in the YMDD motif of the polymerase gene. ${ }^{56}$ Recurrence was observed mainly in patients with a high level of HBV replication prior to drug exposure. In contrast, a similar regimen with ADV exhibited superior efficacy to LAM. In a study of 61 LAM-resistant patients who underwent $L T, 40 \%$ of which received ADV plus/minus LAM prophylaxis without HBIG, no patient had recurrent HBV infection. ${ }^{34}$ Further, a combination of LAM and ADV was superior to ADV alone, as demonstrated by Gane and colleagues. In their study, no recurrence was observed after a median of 22 months in 18 patients (all with HBV DNA below 3 log $10 \mathrm{IU} / \mathrm{ml}$ before $\mathrm{LT}$ ) treated with combination prophylaxis without HBIG. ${ }^{56}$ Similar results were reported for switching from HBIG after a finite period to a combination of LAM/ $\mathrm{ADV}^{57}$ or to a combination of emtricitabine/TDF. ${ }^{58}$

The advent of newer and more potent anti-viral drugs with a high genetic barrier to resistance [i.e., ETV or TDF] has led to a decrease in the duration of HBIG use and even to no use of HBIG at all for post-LT HBV prophylaxis. ${ }^{59-61}$ This was demonstrated in a recent systematic review of 519 HBV patients from 17 studies, $^{62}$ in which the efficacy of drugs with high genetic barrier (i.e., ETV or TDF) with or without HBIG as prophylaxis against HBV recurrence after LT were compared to protocols using LAM and HBIG. It was seen that recurrence developed more often in patients under HBIG and LAM than those with ETV or TDF ( $6.1 \%$ versus $1.0 \% ; p<0.001)$, and recurrence in HBIG and LAM was lower, albeit insignificantly, than patients who received a newer NA after discontinuation of HBIG [6.1\% versus 3.9\%; $p=0.52]$. The use of ETV or TDF alone further was shown to have similar antiviral efficacy as compared to HBIG in combination with LAM, [0.9\% vs. $3.8 \%$, $p=0.11]$.

Table 2 shows studies that examined low dose HBIG in patients for the prevention of HBV recurrence post-LT in combination with LAM.

Although the data are not strong enough to suggest the efficacy of monoprophylaxis with ETV or TDF in reducing post-LT recurrence, this approach continues to be followed in some centers, particularly in patients considered at low-risk of HBV recurrence. Cholangitas et al. showed the effectiveness of this approach in 47 recipients of LT who had low-risk of HBV recurrence (4.5\% with detectable HBV DNA at the time of LT and $32 \%$ with HBV/HDV co-infection) on newer NAs (ETV and TDF monoprophylaxis) after discontinuation of HBIG. It was seen that recurrence occurred in only three $(6.3 \%)$ patients based on detectable HBsAg, while all these patients had undetectable HBV DNA and no clinical symptoms secondary to recurrence. ${ }^{63}$ Similar encouraging results were shown by another study investigating the efficacy of ETV as monoprophylaxis in 80 patients, wherein no episodes of HBV flares or graft loss were reported secondary to recurrent HBV infection. ${ }^{64}$ Another large and long-term cohort study of 362 CHB post-LT patients receiving only NAs without HBIG showed that at year 8 after LT, $98 \%$ had undetectable HBV DNA. Moreover, the survival was also excellent, i.e., $83 \%$ at 8 years, with no mortality related to HBV recurrence. ${ }^{65}$ This clearly shows that an HBIG-free regimen with high potency anti-virals (ETV or TDF) is safe, effective, and an appropriate therapeutic approach, specifically in patients with low risk of HBV recurrence. ${ }^{66,67}$ In high-risk patients, HBIG still constitutes an integral part of the antiviral prophylaxis in many transplant centers. Therefore, HBIG free prophylaxis should not be used for those patients with high pretransplant HBV DNA levels, those with limited antiviral options if HBV recurrence occurs (i.e., human immunodeficiency virus (HIV) or HDV coinfection, preexisting drug resistance, or intolerance), those with a HCC at LT, and those with a risk of noncompliance to antiviral therapy. ${ }^{68}$ Amongst these highrisk groups of patients, a withdrawal of HBIG can still be considered with use of high potency NAs, as discussed. The exact time to consider such withdrawal is still controversial; and studies have shown that discontinuation of HBIG 1 year post-transplantation seems to be a safe and feasible approach. ${ }^{55,63}$ In a recent study from India, withdrawal of HBIG therapy 1 year after LT along with use of high potency NAs (ETV and TDF) for the initial 3 months was studied. They included 176 patients (with at least 12 months follow-up) who had HBV cirrhosis or HCC and underwent LT. All included patients received 10,000 IU IVHBIG in an hepatic phase followed by 600-1000 IU IM daily for 7 days, weekly for 3 weeks, and then monthly, to keep anti-HBs levels $>100 \mathrm{mIU} / \mathrm{mL}$ for 1 year. Further, all these patients received either ETV $(n=126$, $71.5 \%)$ or TDF $(n=20,11.3 \%)$, or a combination of ETV and $\operatorname{TDF}$ ( $n=30,17 \%$ for 3 months, followed by ETV alone). Recurrence was noted only in two patients (one of which was due to noncompliance to therapy) during follow-up of 43 (12-117) months. ${ }^{69}$ 
Maiwall R. et al: Recurrent HBV after Liver Transplantation

Table 2. Studies on low dose HBIG in combination with lamivudine (LAM) to prevent HBV recurrence post-LT

\begin{tabular}{|c|c|c|c|c|c|c|c|}
\hline Reference & $\begin{array}{l}\text { Number } \\
\text { of patients }\end{array}$ & $\begin{array}{l}\text { Anti-viral } \\
\text { pre-LT [\%] }\end{array}$ & $\begin{array}{l}\text { DNA at LT } \\
{[\mathrm{IU} / \mathrm{mL}]}\end{array}$ & HBIG protocol & $\begin{array}{l}\text { Follow up } \\
\text { [months] }\end{array}$ & $\begin{array}{l}\text { Recurrence } \\
{[\%]}\end{array}$ & Antivirals \\
\hline $\begin{array}{l}\text { Angus } \\
\text { et al. }{ }^{55}\end{array}$ & 32 & 97 & - & $\begin{array}{l}800 \text { IU IM at LT and } \\
\text { daily for } 1 \text { week; } \\
800 \text { IU im monthly }\end{array}$ & 18.4 & 3 & \\
\hline $\begin{array}{l}\text { Ferretti } \\
\text { et al. }{ }^{105}\end{array}$ & 23 & 48 & 13 & $\begin{array}{l}80,000 \text { IU IV in } 1 \text { st } \\
\text { wk; } \\
1200 \text { IU IM to keep } \\
\text { titre> } 100 \text { IU/L }\end{array}$ & 20 & 4 & \\
\hline $\begin{array}{l}\text { Karademir } \\
\text { et al. }{ }^{106}\end{array}$ & 35 & 51 & 14 & $\begin{array}{l}4000 \text { IU IM at LT; } \\
2000 \text { IU daily until } \\
\text { titer > } 200 \text { IU/L and } \\
\text { then to maintain } \\
\text { titres }>100 \mathrm{IU} / \mathrm{L}\end{array}$ & 16 & 6 & $\begin{array}{l}\text { All } \\
\text { lamivudine } \\
\text { resistant } \\
\text { pre-LT }\end{array}$ \\
\hline $\begin{array}{l}\text { Zheng } \\
\text { et al. }{ }^{50}\end{array}$ & 114 & - & 31 & $\begin{array}{l}2000 \text { IU IM at LT; } \\
800 \text { IU IM daily for } \\
6 \text { days, weekly for } \\
3 \text { weeks and then } \\
\text { monthly }\end{array}$ & 15.8 & 14 & $\begin{array}{l}\text { Lamivudine } \\
\text { in } 99 \\
\text { post-LT }\end{array}$ \\
\hline $\begin{array}{l}\text { Gane } \\
\text { et al. }{ }^{44}\end{array}$ & 147 & 85 & $<50$ & $\begin{array}{l}800 \text { IU IM at LT and } \\
\text { daily for } 6 \text { days; } \\
\text { then } 800 \text { IU IM } \\
\text { monthly }\end{array}$ & 61 & 4 & \\
\hline
\end{tabular}

Table 3 shows studies of low dose/HBIG-free protocols in combination with antivirals, i.e., LAM, ADV, ETV, or TDF.

Because HBV DNA persists in serum, liver, or peripheral blood mononuclear cells even 10 years after LT and these reservoirs are considered a source of HBV reinfection even in HBsAg negative patients, indefinite long-term prophylactic therapy is the current standard of care in most patients after LT for CHB. ${ }^{70,71}$

Thus, the assessment of the available data suggest that amongst low risk patients (i.e., those with undetectable HBV DNA levels at the time of transplant), HBIG-free regimens can be used with high potency NAs (ETV or TDF) indefinitely; whereas amongst high risk patients (those with detectable HBV DNA levels at LT, presence of drug-resistant HBV, HIV or HDV coinfection, HCC at LT, or poor compliance to antiviral therapy) 10,000 IU IV HBIG in an hepatic phase should be given followed by 600-1000 IU IM or IV daily for 7 days, then weekly for 3 weeks, and then monthly, to keep anti-HBs levels $>100 \mathrm{mIU} / \mathrm{mL}$ for 1 year. After 1 year, HBIG may be discontinued. High potency NAs should be continued simultaneously indefinitely in these patients (Fig. 1). The Asia Pacific Association for the Study of Liver (APASL) have recently published the guidelines on the prevention of recurrent HBV post-LT. ${ }^{3}$

\section{HBIG replacement with vaccination}

Another fascinating option in HBIG-free protocols is active immunization using HBV vaccines post-transplantation. The strategy remains controversial because of conflicting results from various studies. Success of the vaccine strategy was reported by Sanchez-Fueyo and colleagues in 14 out of 17 $(82 \%)$ cases who were treated with HBIG monotherapy followed by one or two courses of double dose vaccination series. ${ }^{72}$ Similarly, Bienzle et al. reported success of a vaccine that was formulated with the new adjuvants 3-deacylated monophosphoryl lipid A (MPL) and Quillaja saponaria in two groups of $10 \mathrm{LT}$ recipients who were HBsAg positive and HBV DNA negative before transplantation. All patients were vaccinated at weeks $0,2,4,16$, and 18 and subsequently received three additional doses of vaccine $B$ at bimonthly intervals targeting an antibody titer against anti-HBs greater than 500 IU/L. Response was demonstrated in 16 out of 20 patients $(80 \%)$ at a median follow up of 13.5 months. ${ }^{73}$ Subsequently, Angelico et al. investigated the efficacy of a triple course of $\mathrm{HBV}$ vaccination in 17 patients transplanted for $\mathrm{HBsAg}$ positive cirrhosis. The treatment protocol in the first cycle consisted of three double IM doses $(40 \mu \mathrm{g})$ of recombinant vaccine at month 0,1 , and 2 , respectively, which was followed, in nonresponders, by a second cycle of six intradermal $10 \mu \mathrm{g}$ doses every 15 days. Further, the nonresponders received a third cycle identical to the first one. The vaccination was initiated 4.5 months after HBIG discontinuation, and LAM (100 mg/day) was given throughout the study. They showed that a vaccination strategy, despite such an aggressive protocol, was ineffective, with success in only $18 \%$ of patients. ${ }^{74}$ The ineffectiveness of the vaccine strategy was also demonstrated by Weber et al. in 36 patients transplanted for HBV. All received HBIG therapy and an oral antiviral agent from the time of transplant; and subsequently, only 12 patients with a stable postoperative clinical course underwent vaccination after HBIG discontinuation. None of the vaccinated patients maintained HBSAb $\geq 10 \mathrm{IU} / \mathrm{L}^{75}$ Several other trials have also demonstrated poor outcomes with various vaccination strategies, with failure to maintain protective anti-HBs levels over time. ${ }^{76-78}$ The vaccine response is basically determined by the status of immune tolerance in both the donor and the recipient. Patients who are infected with HBV but have still not developed tolerance to the virus, such as patients who develop acute liver failure due to sexual 
Maiwall R. et al: Recurrent HBV after Liver Transplantation

Table 3. Studies on low dose/HBIG-free protocols in combination with antivirals [LAM, adefovir (ADV), entecavir (ETV), or tenofovir (TDF)]

\begin{tabular}{|c|c|c|c|c|c|c|}
\hline Study & $\begin{array}{l}\text { Number of } \\
\text { patients }\end{array}$ & Treatment protocol & Oral NAs & $\begin{array}{l}\mathrm{HBV} \\
\text { recurrence }\end{array}$ & $\begin{array}{l}\text { Follow up } \\
\text { (in months) }\end{array}$ & \\
\hline Perillo et al. ${ }^{65}$ & 47 & No HBIG & LAM & $9 / 22(41 \%)$ & Median 38 & $\begin{array}{l}\text { Resistance } \\
\text { detection } \\
15 / 47(32 \%)\end{array}$ \\
\hline Lo et al. ${ }^{66}$ & 31 & No HBIG & LAM & $1 / 26$ & $\begin{array}{l}26 \text { alive at } \\
\text { median } 16\end{array}$ & $\begin{array}{l}\text { Resistance } \\
\text { detection } \\
1 / 31(3.2 \%) \\
\text { at } 53 \mathrm{wk}\end{array}$ \\
\hline Park et al. ${ }^{67}$ & 43 & $\begin{array}{l}\text { Long term high dose } \\
\text { HBIG }(n=20) \\
1 \text { week high dose HBIG }+ \\
\text { LMV maintenance } \\
(n=23)\end{array}$ & LAM & $\begin{array}{l}1 / 20(5 \%) \text { in } \\
\text { HBIG } \\
3 / 23(13 \%) \\
\text { in LMV } \\
\text { maintenance }\end{array}$ & Median 17 & \\
\hline Buti et al. ${ }^{53,54}$ & 29 & $\begin{array}{l}\text { HBIG and LMV } \\
\text { for } 1 \text { month then } \\
\text { randomized to } \\
\text { HBIG }+ \text { LMV continuation } \\
(n=15) \text { or } \\
\text { solo LMV }(n=14)\end{array}$ & LAM & $\begin{array}{l}1 / 15(6.7 \%) \\
\text { in the HBIG } \\
+ \text { LMV group } \\
3 / 14 \\
(21.4 \%) \text { in } \\
\text { the LMV } \\
\text { group }\end{array}$ & Mean 83 & \\
\hline Wong et al. ${ }^{107}$ & 21 & $\begin{array}{l}\text { At least seven doses of } \\
\text { HBIG }\end{array}$ & LAM & $1 / 21(4.7 \%)$ & Median 40 & \\
\hline Angus et al. ${ }^{55}$ & 34 & $\begin{array}{l}\text { Low dose IM HBIG + LAM } \\
(n=18) \text { versus. }(n=16) \\
\text { discontinued HBIG and } \\
\text { Added (LMV + ADV) } \\
\text { post-LT }\end{array}$ & $\begin{array}{l}\text { LAM } \\
\text { LAM+ADF }\end{array}$ & $\begin{array}{l}0 / 18 \text { in HBIG } \\
+ \text { LMV } \\
1 / 16(6.3 \%) \\
\text { in LMV + } \\
\text { ADV }\end{array}$ & Median 34 & $\begin{array}{l}\text { All patients } \\
\text { were } \geq 12 \\
\text { months post- } \\
\text { LT }\end{array}$ \\
\hline Yuefeng et al. ${ }^{108}$ & 15 & $\begin{array}{l}\text { HBIG for less than } 18 \\
\text { months }\end{array}$ & LAM & $2 / 15(13 \%)$ & Mean 56 & \\
\hline Saab et al. ${ }^{109}$ & 61 & $\begin{array}{l}\text { IM HBIG for at least } 12 \\
\text { months }\end{array}$ & $\begin{array}{l}\text { LAM } \\
\text { LAM+ADF } \\
\text { ETV+ADF } \\
\text { TNF }\end{array}$ & $2 / 61(3.3 \%)$ & Mean 15 & \\
\hline Fung et $a l .^{60}$ & 23 & No HBIG & ETV & $18 / 80(23 \%)$ & Median 26 & \\
\hline Wadhawan et al. ${ }^{61}$ & 75 & No HBIG & $\begin{array}{l}\text { LAM + ADV } \\
(19) \\
\text { ETV (42) } \\
\text { TDF (12) } \\
\text { ETV + TDF } \\
(2)\end{array}$ & $6 / 75(8 \%)$ & Median 21 & \\
\hline $\begin{array}{l}\text { Degertekin } \\
\text { et al. }{ }^{51}\end{array}$ & 23 & HBIG for 12 months & $\begin{array}{l}\text { LAM } \\
\text { ADV } \\
\text { ETV } \\
\text { TDF } \\
\text { LAM + ADV } \\
\text { LAM + TDF } \\
\text { ETV + ADV } \\
\text { TDF + ADV }\end{array}$ & $3 / 23(13 \%)$ & Median 53 & \\
\hline Nath et al. ${ }^{110}$ & 14 & HBIG for 7 days & LAM + ADV & $0 / 14(0)$ & Median 14 & \\
\hline Teperman et al. ${ }^{58}$ & 16 & HBIG for 6 months & FTC + TDF & $0 / 16(0)$ & Median 22 & \\
\hline Neff et al. ${ }^{111}$ & 10 & HBIG for 7 months & LAM + ADV & $0 / 10(0)$ & Mean 31 & \\
\hline
\end{tabular}

transmission, and those who receive anti-HBc positive donor livers are good candidates for vaccine strategy. ${ }^{79}$ Another protocol of repeated vaccine administration has been shown to be successful via adoptive transfer of HBV-specific immune response in patients with post-OLT liver cirrhosis. ${ }^{80}$ In particular, this was seen in donors who were spouses of patients infected with HBV and had high titer anti-HBs before donation. ${ }^{80}$ Lu et al. showed that a titer of more than $1000 \mathrm{IU} / \mathrm{L}$ 
Maiwall R. et al: Recurrent HBV after Liver Transplantation

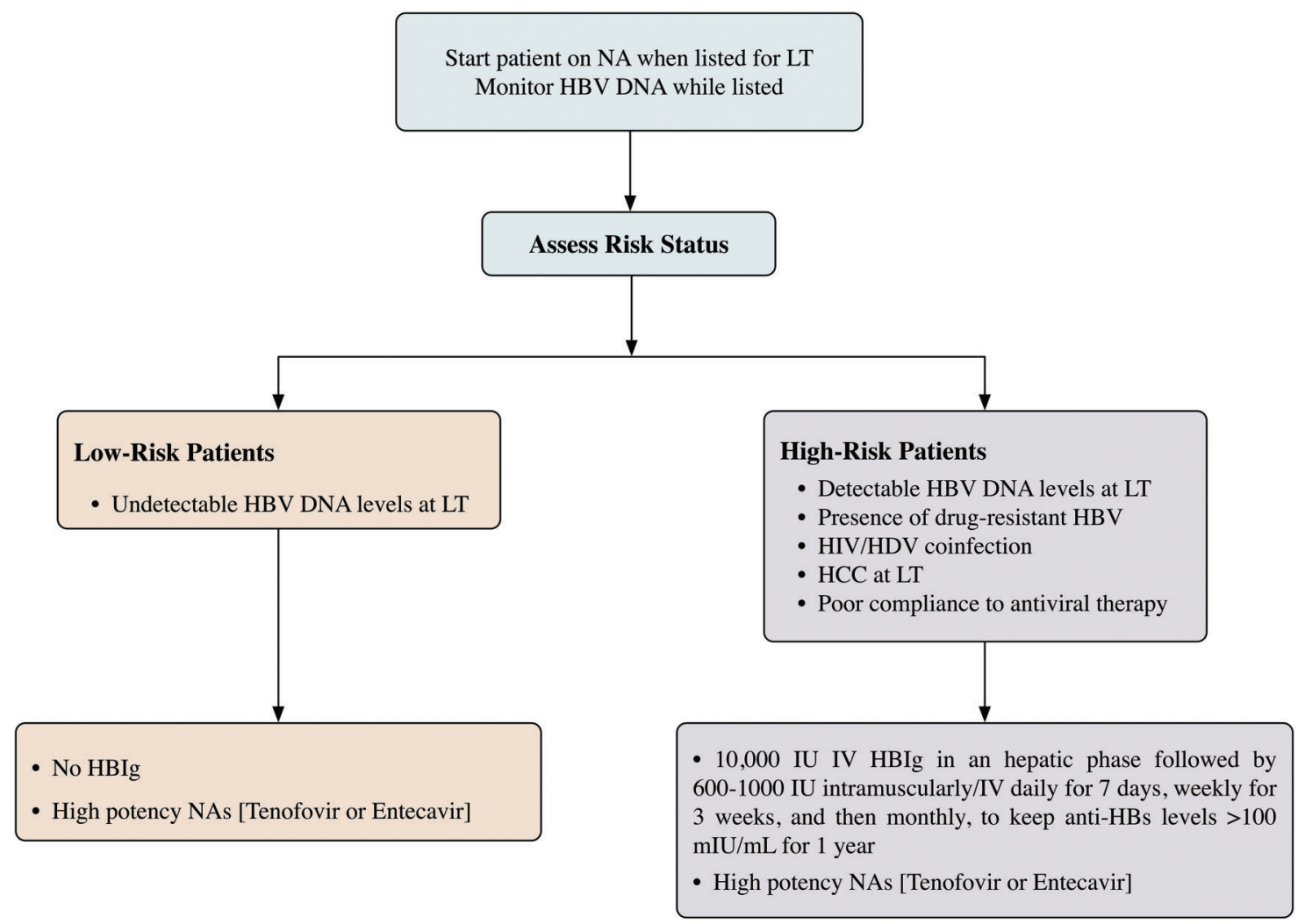

Fig. 1. Proposed algorithm for HBV prophylaxis using HBIG and nucleosides/nucleotides analogues. Abbreviations: HBIG, hepatitis $B$ immune globulin; HBV, hepatitis B virus; HDV, hepatitis delta virus; anti-HBs, hepatitis B surface antibody; LT, liver transplantation; NAs, nucleos(t)ide analogues.

for anti-HBs is required for adoptive transfer of immunity in these patients. ${ }^{81}$

Recent data have emerged that suggest the vaccination strategy can be improved by administration of booster doses, double dose third generation recombinant vaccines, or the addition of adjuvants given with the vaccine, which can decrease the formation of escape mutants and the subsequent failure of therapy. ${ }^{20,82,83}$

Overall, the data regarding use of vaccines is encouraging, but large prospective studies are needed still before such a strategy could be recommended routinely in clinical practice.

\section{Use of grafts from core positive donors}

Considering the organ shortage, use of marginal liver grafts obtained from anti-HBc positive donors are frequently considered for patients with HBsAg positive liver disease in countries with high prevalence of this virus. However, there is a risk of virus reactivation post-LT due to the influence of immunosuppression. ${ }^{84}$ Cholongitas and colleagues performed a systematic review of 903 recipients from 39 studies for both the risk of HBV infection after LT with such grafts and the effect of anti-HBV prophylaxis after post-LT recurrence. ${ }^{85}$ Recurrence of HBV infection was noted in $11 \%$ of HBsAg-positive LT recipients of anti-HBc positive grafts without any difference in survival when compared to HBsAgpositive recipients of anti-HBc negative grafts. Further, denovo HBV infection developed in $19 \%$ of $\mathrm{HBsAg}$-negative recipients. Re-infection was more frequent in anti-HBc/
anti-HBs positive than HBV naïve cases without prophylaxis (15\% vs 48\%, $p<0.001)$. Prophylaxis with HBV included HBIG, LAM, or a combination of both. Use of prophylaxis led to decreased rates of re-infection. The de novo infection rates were $19 \%, 2.6 \%$, and $2.8 \%$ in $\mathrm{HBsAg}$-negative recipients under HBIG, LAM, and their combination, respectively.

Based on these results, it was suggested that anti-HBc positive donors can be used safely in HBsAg positive or anti$\mathrm{HBC} / a n t i-H B s$ positive recipients. Further, patients who are HBsAg-negative should receive prophylaxis with antivirals, and patients who are both anti-HBc/anti-HBs positive recipients may need no prophylaxis at all (Fig. 2). These grafts should be first offered to HBsAg positive, then to anti-HBC and/or HBs positive, and only in the end should be allocated to hepatitis B virus naïve (both anti-HBc and anti-HBs negative) recipients, considering the increased risk of reactivation in the last subgroup of patients

\section{Post-LT HBV Prophylaxis Failure}

Because of the persistence of HBV DNA in serum, liver, or peripheral blood mononuclear cells even several years after LT, long-term prophylactic therapy has been recommended for these patients. However, long-lasting treatment in these patients carries a potential risk of prophylaxis failure because of the selection of drug resistant mutants to NAs and HBIG. ${ }^{86}$ The lower diversity of anti-HBs contained in HBIG is one potential reason for HBIG resistance. ${ }^{87}$ The common mutations that have been identified include G145R, G145A, or 


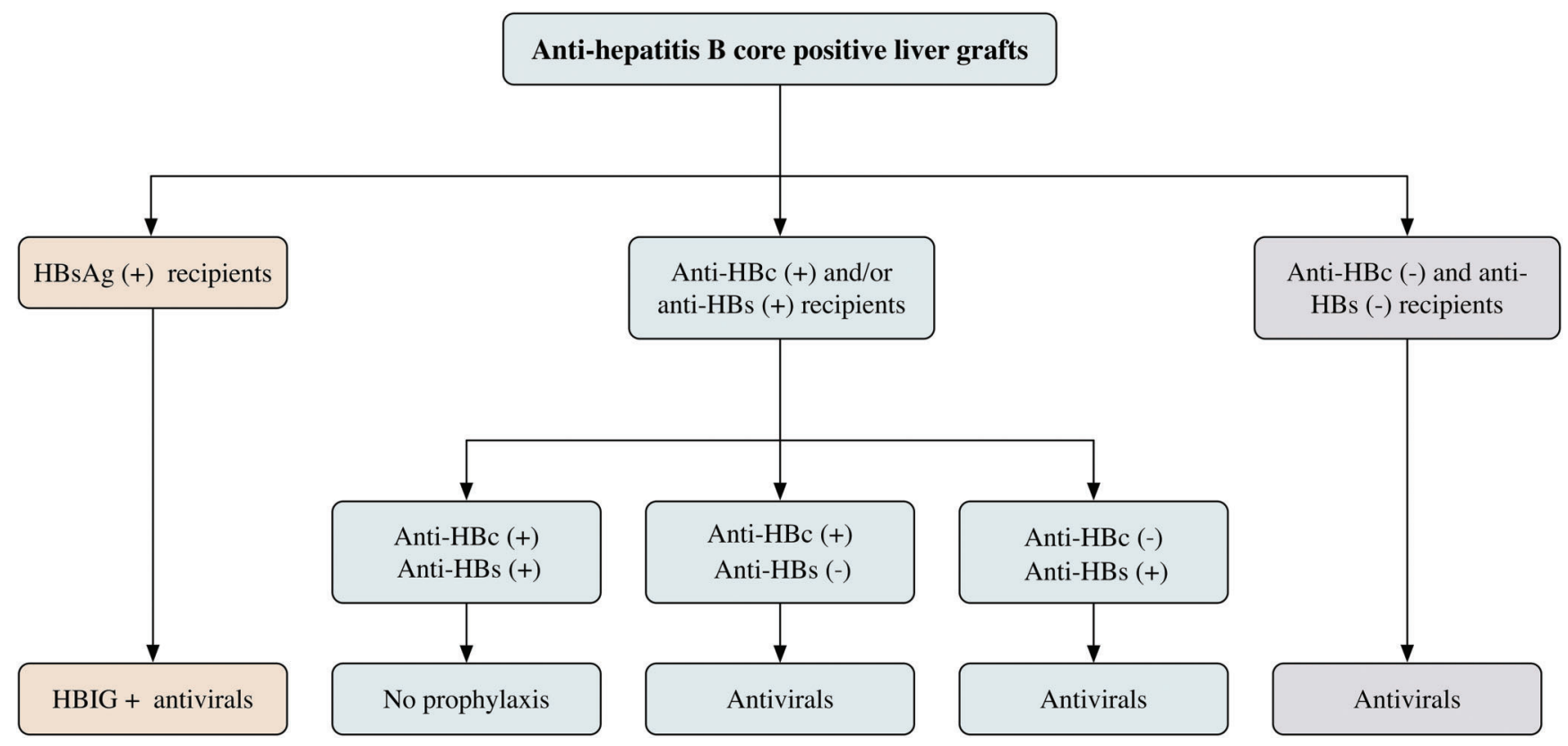

Fig. 2. Proposed algorithm for allocation and management of anti-HBc positive liver grafts. According to the available evidence, these grafts should be offered first to $\mathrm{HBsAg}$ positive patients, then to $\mathrm{HBC}$ and/or $\mathrm{HBs}$ positive patients, and only in the end should be allocated to hepatitis B virus naïve (both anti-HBc and anti-HBs negative) recipients, because of the increased risk of reactivation in the last subgroup of patients. Abbreviations: HBsAg, hepatitis B surface antigen; anti-HBs, hepatitis B surface antibody; HBIG, hepatitis B immunoglobulin.

Q129P. ${ }^{88}$ Additionally, longer administration of NAs also involves other problems, such as osteomalacia, Fanconi's syndrome with $A D V^{89,90}$ and allergic reactions with HBIG.

\section{Emerging Drug Targets for HBV infection}

As already mentioned, NAs do not eliminate cccDNA and; therefore, there is an ongoing discovery for compounds that could directly target cccDNA. Replication of HBV in infected hepatocytes is primarily regulated by acetylation or methylation of histone proteins. The hSirt1/2 activator MC2791 and the JMJD3 inhibitor MC3119 are important drugs that have been tested as epigenetic silencers of cccDNA. Other drug targets that have been evaluated include small-molecule compounds, i.e., CCC-0975 and CCC-0346. ${ }^{91,92}$ Another promising therapeutic approach that has been investigated is blocking the entry receptor of HBV on the hepatocyte. Myrcludex-B is a synthetic lipopeptide derived from the HBV envelope protein that inactivates the HBV pre-S1 receptor, ${ }^{93}$ and it has been tested in phase 2 trials. ${ }^{93,94}$ Future studies are needed to explore whether a combination of HBIG (targeting the AGL domain) and Myrcludex B (targeting the pre-S1 receptor) as a possible approach to prevent re-infection. A more effective vaccine also has the possibility to induce easier and stronger HBV prophylaxis. Use of several monoclonal antibodies that have stronger reactivity to $\mathrm{HBsAg}$ are other options to enable HBsAg clearance. Another novel drug target that has been identified includes the hepatocyte NTCP receptor, ${ }^{25,26}$ which is localized to the sinusoidal membrane and is involved in the enterohepatic circulation of bile salts. Partial blocking of NTCP could result in blocking HBV entry into the hepatocytes and could constitute an important therapeutic modality in preventing viral recurrence post-LT, which needs evaluation in future studies. Considering an inherent potential of the immune system in the clearance of
HBV infection and recent research suggesting clearance of chronic HBV in patients who get bone marrow transplantation from an immune donor, the significance of immunomodulation as a therapeutic approach has been explored for achieving viral clearance in patients with chronic HBV. ${ }^{95,96}$ Immunotherapeutic strategies that are under development for patients with $\mathrm{CHB}$ include exogenous administration of cytokines with antiviral activity (IFN- $\lambda$ ) and stimulation of the host $T$ cell immune response. GS-9620, a small orally bioavailable molecule that activates Toll-like receptor 7 signaling, has also been tested in animal models and is currently being evaluated in clinical trials for patients with chronic HBV. ${ }^{97-101}$

Thus, although the future therapies for HBV infection has an exciting pipeline, human studies, especially in the context of $L T$ recipients, are needed.

\section{Conclusions}

Based on the current evidence, all HBV patients with decompensated cirrhosis should be treated with potent antivirals with high genetic barrier to resistance (ETV or TDF). ETV should be avoided in patients with a previous history of LAM resistance; and, in such patients, TDF should be the drug of choice. TDF should also be the first choice in patients with ETV or telbivudine resistance. Effective pretransplant treatment is the most important factor determining post-transplant HBV recurrence.

To prevent post-LT recurrence, patients with undetectable HBV DNA levels at the time of transplant can be managed using HBIG-free protocols with a high potency antiviral, preferably TDF or ETV. Protocols using short-term HBIG for a year targeting anti-HBs $>100 \mathrm{mIU} / \mathrm{mL}$ can be an appropriate therapeutic approach for high-risk patients (i.e., detectable HBV DNA levels at LT, HCC at LT, HIV or HDV coinfection, preexisting drug resistance or intolerance, or those with a risk 
of noncompliance to antiviral therapy). Finally, marginal grafts from anti-HBc positive donors can be safely used in HBsAg negative, preferably in anti-HBc/anti-HBs positive recipients. Novel drugs that target ccCDNA or the NTCP receptor for viral entry or that modulate the immune system hold a lot of promise, which needs to be assessed in future studies. These drugs could not only eliminate the need for life-long therapy but may also cure HBV.

\section{Conflict of interest}

None

\section{Author contributions}

Writing the article (RM, MK).

\section{References}

[1] http://www.who.int/mediacentre/factsheets/fs204/en/. Accessed 2 Feb 2016.

[2] Samuel D, Muller R, Alexander G, Fassati L, Ducot B, Benhamou JP, et al. Liver transplantation in European patients with the hepatitis $B$ surface antigen. N Engl J Med 1993;329:1842-1847. doi: 10.1056/ NEJM199312163292503.

[3] Sarin SK, Kumar M, Lau GK, Abbas Z, Chan HL, Chen CJ, et al. Asian-Pacific clinical practice guidelines on the management of hepatitis B: a 2015 update. Hepatol Int 2016;10:1-98. doi: 10.1007/s12072-015-9675-4.

[4] Takaki A, Yagi T, Yamamoto K. Contradictory immune response in post liver transplantation hepatitis B and C. Int J Inflam 2014;2014:814760. doi: 10. $1155 / 2014 / 814760$.

[5] Schuch A, Hoh A, Thimme R. The role of natural killer cells and CD8(+) $T$ cells in hepatitis $B$ virus infection. Front Immunol 2014;5:258. doi: 10 . 3389/fimmu.2014.00258.

[6] Schurich A, Khanna P, Lopes AR, Han KJ, Peppa D, Micco L, et al. Role of the coinhibitory receptor cytotoxic $T$ lymphocyte antigen-4 on apoptosis-Prone CD8 T cells in persistent hepatitis B virus infection. Hepatology $2011 ; 53$ : 1494-1503. doi: 10.1002/hep.24249.

[7] Fisicaro P, Valdatta C, Massari M, Loggi E, Biasini E, Sacchelli L, et al. Antiviral intrahepatic T-cell responses can be restored by blocking programmed death-1 pathway in chronic hepatitis B. Gastroenterology 2010;138:682-693.e1-4.

[8] Nebbia G, Peppa D, Schurich A, Khanna P, Singh HD, Cheng Y, et al. Upregulation of the Tim-3/galectin-9 pathway of T cell exhaustion in chronic hepatitis B virus infection. PLoS One 2012;7:e47648. doi: 10.1371/journal.pone.0047648.

[9] Takaki A, Yasunaka T, Yagi T. Molecular Mechanisms to Control PostTransplantation Hepatitis B Recurrence. Int J Mol Sci. 2015;16:1749417513. doi: $10.3390 /$ ijms 160817494.

[10] Urban S, Bartenschlager R, Kubitz R, Zoulim F. Strategies to inhibit entry of HBV and HDV into hepatocytes. Gastroenterology 2014;147:48-64. doi: 10.1053/j.gastro.2014.04.030.

[11] Seitz S, Urban S, Antoni C, Bottcher B. Cryo-electron microscopy of hepatitis $B$ virions reveals variability in envelope capsid interactions. EMBO 2007; 26:4160-4167. doi: 10.1038/sj.emboj.7601841.

[12] Bruss V. Hepatitis B virus morphogenesis. World J Gastroenterol 2007;13: 65-73. doi: 10.3748/wjg.v13.i1.65.

[13] Glebe D, Urban S, Knoop EV, Cag N, Krass P, Grun S, et al. Mapping of the hepatitis $B$ virus attachment site by use of infection-inhibiting pres1lipopeptides and tupaia hepatocytes. Gastroenterology 2005;129:234-245. doi: $10.1053 /$ j.gastro.2005.03.090.

[14] Ryu CJ, Gripon P, Park HR, Park SS, Kim YK, Guguen-Guillouzo C, et al. In vitro neutralization of hepatitis $B$ virus by monoclonal antibodies against the viral surface antigen. J Med Virol 1997;52:226-233. doi: 10. 1002/(SICI)1096-9071(199706)52:2<226::AID-JMV18>3.0.CO;2-I.

[15] Schilling R, Ijaz S, Davidoff M, Lee JY, Locarnini S, Williams R, et al. Endocytosis of hepatitis $B$ immune globulin into hepatocytes inhibits the secretion of hepatitis B virus surface antigen and virions. J Virol 2003;77: 88828892. doi: 10.1128/JVI.77.16.8882-8892.2003.

[16] Yasunaka T, Takaki A, Yagi T, Iwasaki Y, Sadamori H, Koike K. Serum hepatitis $B$ virus DNA before liver transplantation correlates with $\mathrm{HBV}$ reinfection rate even under successful low-dose hepatitis B immunoglobulin prophylaxis. Hepatol Int 2011;5:918-926. doi: 10.1007/s12072-011-9265-Z.

[17] Levrero M, Pollicino T, Petersen J, Belloni L, Raimondo G, Dandri M, et al. Control of cccDNA function in hepatitis B virus infection. J. Hepatol 2009; 51:581-592. doi: 10.1016/j.jhep.2009.05.022.
[18] Rehermann B, Ferrari C, Pasquinelli C, Chisari FV. The hepatitis B virus persists for decades after patients recovery from acute viral hepatitis despite active maintenance of a cytotoxic T-lymphocyte response. Nat Med 1996;2:1104-1108. doi: 10.1038/nm1096-1104.

[19] Terrault NA, Zhou S, Combs C, Hahn JA, Lake JR, Roberts JP, et al. Prophylaxis in liver transplant recipients using a fixed dosing schedule of hepatitis B immunoglobulin. Hepatology 1996;24:1327-1333. doi: 10.1002/hep. 510240601.

[20] Fox AN, Terrault NA. The option of HBIG-free prophylaxis against recurrent HBV. J Hepatol 2012;56:1189-1197. doi: 10.1016/j.jhep.2011.08.026.

[21] Mutimer D, Pillay D, Dragon E, Tang H, Ahmed M, O'Donnell K, et al. High pre-treatment serum hepatitis $\mathrm{B}$ virus titre predicts failure of lamivudine prophylaxis and graft re-infection after liver transplantation. J Hepatol 1999;30:715-721. doi: 10.1016/S0168-8278(99)80204-9.

[22] Rosenau J, Bahr MJ, Tillmann HL, Trautwein C, Klempnauer J, Manns MP, et al. Lamivudine and low-dose hepatitis B immune globulin for prophylaxis of hepatitis $B$ reinfection after liver transplantation possible role of mutations in the YMDD motif prior to transplantation as a risk factor for rein-fection. J Hepatol 2001;34:895-902. doi: 10.1016/S0168-8278(01)00089-7.

[23] Marzano A, Salizzoni M, Debernadi-Venon W, Smedile A, Franchello A, Ciancio $A$, et al. Prevention of hepatitis $B$ virus recurrence after liver transplantation in cirrhotic patientstreated with lamivudine and passive immunoprophylaxis. J Hepatol 2001;34: 903-910. doi: 10.1016/S0168-8278(01)00080-0.

[24] Yan H, Zhong G, Xu G, He W, Jing Z, Gao Z, et al. Sodiumtaurocholatecotransporting polypeptide is a functional receptor for human hepatitis $B$ and D virus. Elife $2012 ; 13 ; 1: e 00049$

[25] Nkongolo S, Ni Y, Lempp FA, Kaufman C, Lindner T, Esser-Nobis K, et al. Cyclosporin A inhibits hepatitis $B$ and hepatitis $D$ virus entry by cyclophilinindependent interference with the NTCP receptor. J Hepatol 2014;60:723731. doi: 10.1016/j.jhep.2013.11.022.

[26] Tsukuda S, Watashi K, Iwamoto M, Suzuki R, Aizaki H, Okada M, et al. Dysregulation of retinoic acid receptor diminishes hepatocyte permissiveness to hepatitis $B$ virus infection through modulation of sodium taurocholate cotransporting polypeptide (NTCP) expression. J Biol Chem 2015;290: 5673-5684. doi: 10.1074/jbc.M114.602540.

[27] Matsui T, Kang JH, Nojima M, Tomonari A, Aoki H, Yamazaki H, et al. Reactivation of hepatitis $B$ virus in patients with undetectable HBsAg undergoing chemotherapy for malignant lymphoma or multiple myeloma. J Med Virol 2013;85:1900-1906. doi: 10.1002/jmv.23694.

[28] Uemoto S, Sugiyama K, Marusawa H, Inomata Y, Asonuma K, Egawa H, et al. Transmission of hepatitis B virus from hepatitis B core antibodypositive donors in living related liver transplants. Transplantation 1998; 65:494-499. doi: 10.1097/00007890-199802270-00007.

[29] Maini MK, Boni C, Ogg GS, King AS, Reignat S, Lee CK, et al. Direct ex vivo analysis of hepatitis B virus-specific CD8 $(+)$ T cells associated with the control of infection. Gastroenterology 1999;117:1386-1396. doi: 10. 1016/S0016-5085(99)70289-1.

[30] Schuch A, Hoh A, Thimme R. The role of natural killer cells and CD8(+) $T$ cells in hepatitis B virus infection. Front Immunol 2014;5:258. doi: 10 . 3389/fimmu.2014.00258.

[31] Boni C, Fisicaro P, Valdatta C, Amadei B, di Vincenzo P, Giuberti T, et al. Characterization of hepatitis $B$ virus (HBV)-specific T-cell dysfunction in chronic HBV infection. J Virol 2007;81:4215-4225.

[32] Degos F, Lugassy C, Degott C, Debure A, Carnot F, Theirs V, et al. Hepatitis B virus and hepatitis B-related viral infection in renal transplant recipients. A prospective study of 90 patients. Gastroenterology 1988;94:151-156.

[33] Demetris AJ, Jaffe R, Sheahan DG, Burnham J, Spero J, Iwatsuki S, et al. Recurrent hepatitis $B$ in liver allograft recipients. Differentiation between viral hepatitis B and rejection. Am J Pathol 1986;125:161-172.

[34] Schiff E, Lai CL, Hadziyannis S, Neuhaus P, Terrault N, Colombo M, et al. Adefovir Dipivoxil Study 45 Intrnational Investigators Group. Adefovir dipivoxil for wait-listed and post-liver transplantation patients with lamivudine-resistant hepatitis B: final long-term results. Liver Transpl 2007;13: 349-360. doi: 10.1002/It.20981.

[35] Shouval D, Samuel D. Hepatitis B, immune globulin to prevent hepatitis $B$ virus graft reinfection following liver transplantation: a concise review. Hepatology 2000;32:1189-1195. doi: 10.1053/jhep.2000.19789.

[36] McGory RW, Ishitani MB, Oliveira WM, Stevenson WC, McCullough CS, Dickson $\mathrm{RC}$, et al. Improved outcome of orthotopic liver transplantation for chronic hepatitis $B$ cirrhosis with aggressive passive immunization. Transplantation 1996;61:1358-1364. doi: 10.1097/00007890-199605150-00013.

[37] Faria LC, Gigou M, Roque-Afonso AM, Sebagh M, Roche B, Fallot G, et al. Hepatocellular carcinoma is associated with an increased risk of hepatitis $B$ virus recurrence after liver transplantation. Gastroenterology 2008;134: 1890-1899. doi: 10.1053/j.gastro.2008.02.064.

[38] Marzano A, Gaia S, Ghisetti V, Carenzi S, Premoli A, Debernardi-Venon W, et al. Viral load at the time of liver transplantation and risk of hepatitis $B$ virus recurrence. Liver Transpl 2005;11:402-409. doi: 10.1002/It.20402.

[39] Mutimer D, Pillay D, Dragon E, Tang H, Ahmed M, O'Donnell K, et al. High pre-treatment serum hepatitis $\mathrm{B}$ virus titre predicts failure of lamivudine 
prophylaxis and graft re-infection after liver transplantation. ] Hepatol 1999;30:715-721. doi: 10.1016/S0168-8278(99)80204-9.

[40] Rosenau J, Tillmann HL, Bahr MJ, Trautwein C, Boeker KH, Nashan B, et al. Successful hepatitis $B$ reinfection prophylaxis with lamivudine and hepatitis B immune globulin in patients with positive HBV-DNA at time of liver transplantation. Transplant Proc 2001;33:3637-3638. doi: 10.1016/ S0041-1345(01)02564-7.

[41] Todo S, Demetris AJ, van Thiel D, Teperman L, Fung J], Starzl TE, et al. Orthotopic liver transplantation for patients with hepatitis B virus-related liver disease. Hepatology 1991;13:619-626. doi: 10.1002/hep.1840130402.

[42] Lerut JP, Donataccio M, Ciccarelli O, Roggen F, Jamart J, Laterre PF, et al. Liver transplantation and HBsAg-positive postnecrotic cirrhosis: Adequate immunoprophylaxis and delta virus co-infection as the significant determinants of long-term prognosis. J Hepatol 1999;30:706-714. doi: 10. 1016/S0168-8278(99)80203-7.

[43] Demetris AJ, Todo S, van Thiel DH, Fung JJ, Iwaki Y, Sysyn G, et al. Evolution of hepatitis $B$ virus liver disease after hepatic replacement. Practical and theoretical considerations. Am J Pathol 1990;137:667-676.

[44] Gane EJ, Angus PW, Strasser S, Crawford DH, Ring J, Jeffrey GP, et al. Lamivudine plus low-dose hepatitis $B$ immunoglobulin to prevent recurrent hepatitis B following liver transplantation.Gastroenterology 2007;132: 931-937. doi: 10.1053/j.gastro.2007.01.005.

[45] Katz LH, Tur-Kaspa R, Guy DG, Paul M. Lamivudine or adefovirdipivoxilaloneor combined with immunoglobulin for preventing hepatitis $B$ recurrence after liver transplantation. Cochrane Database Syst Rev 2010;7:CD006005.

[46] Markowitz JS, Martin P, Conrad AJ, Markmann JF, Seu P, Yersiz H, et al. Prophylaxis against hepatitis $B$ recurrence following liver transplantation using combination lamivudine and hepatitis B immuneglobulin. Hepatology 1998;28:585-589. doi: 10.1002/hep.510280241.

[47] Han SH, Ofman J, Holt C, King K, Kunder G, Chen P, et al. An efficacy and cost-effectiveness analysis of combination hepatitis $B$ immune globulin and lamivudine to prevent recurrent hepatitis B after orthotopiclivertransplantation compared with hepatitis B immune globulin monotherapy. Liver Transpl 2000;6:741-748. doi: 10.1053/jlts.2000.18702.

[48] Rao W, Wu X, Xiu D. Lamivudine or lamivudine combined with hepatitis B immunoglobulin in prophylaxis of hepatitis $B$ recurrence after liver transplantation: a meta-analysis. Transpl Int 2009;22:387-394. doi: 10.1111/j. 1432-2277.2008.00784.x.

[49] Di Costanzo GG, Lanza AG, Picciotto FP, Imparato M, Migliaccio C, De Luca M, et al. Safety and efficacy of subcutaneous hepatitis B immunoglobulin after liver transplantation: an opensingle-arm prospective study. Am J Transplant 2013;13:348-352. doi: 10.1111/j.1600-6143.2012.04319.x.

[50] Zheng S, Chen Y, Liang T, Lu A, Wang W, Shen Y, et al. Prevention of hepatitis $B$ recurrence after liver transplantation using lamivudine or lamivudine combined with hepatitis B Immunoglobulin prophylaxis. Liver Transpl 2006;12:253-258. doi: 10.1002/It.20701.

[51] Degertekin B, Han SH, Keeffe EB, Schiff ER, Luketic VA, Brown RS Jr, et al. NIH HBV-OLT Study Group. Impact of virologic breakthrough and HBIG regimen on hepatitis $B$ recurrence after liver transplantation. Am J Transplant 2010;10:1823-1833. doi: 10.1111/j.1600-6143.2010.03046.x.

[52] Cholongitas E, Goulis ], Akriviadis E, Papatheodoridis GV. Hepatitis B immunoglobulin and/or nucleos(t)ide analogues for prophylaxis against hepatitis b virus recurrence after liver transplantation: a systematic review. Liver Transpl 2011;17:1176-1190. doi: 10.1002/lt.22354.

[53] Buti M, Mas A, Prieto M, Casafont F, González A, Miras M, et al. A randomized study comparing lamivudine monotherapyafter a short course of hepatitis $B$ immune globulin (HBIg) and lamivudine with longterm lamivudine plus HBIg in the prevention of hepatitis $B$ virus recurrence after liver transplantation. J Hepatol 2003;38:811-817. doi: 10.1016/S0168-8278(03)00087-4.

[54] Buti M, Mas A, Prieto M, Casafont F, González A, Miras M, et al. Adherence to Lamivudine after an early withdrawal of hepatitis $B$ immune globulin plays an important role in the long-term prevention of hepatitis B virus recurrence. Transplantation 2007;84:650-654. doi: 10.1097/01.tp. 0000277289.23677.0a.

[55] Angus PW, Patterson S], Strasser SI, Mc-Caughan GW, Gane E. A randomized study of adefovirdipivoxil in place of HBIG in combination with lamivudine as post-liver transplantation hepatitis B prophylaxis. Hepatology 2008 48:1460-1466. doi: 10.1002/hep.22524.

[56] Gane E, Patterson S, Strasser S, McCaughan G, Angus P. Combination lamivudine plus adefovir without HBIG is safe and effective prophylaxis against HBV recurrence inHBsAg+ liver transplant candidates. Liver Transpl 2013; 19:268-274 doi: 10.1002/It.23600.

[57] Yi NJ, Choi JY, Suh KS, Cho JY, Baik M, Hong G, et al. Post-transplantation sequential entecavir monotherapy following 1 -year combination therapy with hepatitis B immunoglobulin. J Gastroenterol 2013;48:1401-1410. doi 10.1007/s00535-013-0761-x.

[58] Teperman LW, Poordad F, Bzowej N, Martin P, Pungpapong S, Schiano T, et al. Randomized trial of emtricitabine/tenofovir disoproxil fumarate after hepatitis B immunoglobulin withdrawal after liver transplantation. Liver Transpl 2013;19:594-601. doi: 10.1002/It.23628.
[59] Fung J, Cheung C, Chan SC, Yuen MF, Chok KS, Sharr W, et al. Entecavir monotherapy is effective in suppressing hepatitis $B$ virus after liver transplantation. Gastroenterology $2011 ; 141: 1212-1219$. doi: $10.1053 /$ j.gastro. 2011.06.083.

[60] Fung J, Chan SC, Cheung C, Yuen MF, Chok KS, Sharr W, et al. Oral nucleoside/nucleotide analogs without hepatitis B immune globulin after liver transplantation for hepatitis B. Am J Gastroenterol 2013;108:942-948. doi: 10.1038/ajg.2013.111.

[61] Wadhawan M, Gupta S, Goyal N, Taneja S, Kumar A. Living related liver transplantation for hepatitis B-related liverdisease without hepatitis B immune globulin prophylaxis. Liver Transpl 2013;19:1030-1035. doi: 10. 1002/It.23692.

[62] Cholongitas E, Papatheodoridis GV. High genetic barrier nucleos(t)ide analogue(s) for prophylaxis from hepatitis B virus recurrence after liver transplantation: a systematic review. Am J Transplant 2013;13:353-362. doi: 10.1111/j.1600-6143.2012.04315.x.

[63] Cholongitas E, Vasiliadis T, Antoniadis N, Goulis I, Papanikolaou V, Akriviadis $\mathrm{E}$, et al. Hepatitis $\mathrm{B}$ prophylaxis post liver transplantation with newer nucleos(t)ide analogues after hepatitis B immunoglobulin discontinuation. Transpl Infect Dis 2012;14:479-487. doi: 10.1111/j.1399-3062. 2012.00741.x.

[64] Nef GW, Kemmer N, Kaiser TE, Zacharias VC, Alonzo M, Thomas M, et al. Combination therapy in liver transplant recipients with hepatitis $B$ virus without hepatitis B immune globulin. Dig Dis Sci 2007;52:2497-2500. doi: 10.1007/s10620-006-9658-3.

[65] Perrillo RP, Wright T, Rakela J, Levy G, Schiff E, Gish R, et al. A multicenter United States-Canadian trial to assess lamivudine monotherapy before and after liver transplantation for chronic hepatitis B. Hepatology 2001;33:424432. doi: $10.1053 /$ jhep.2001.21554.

[66] Lo CM, Cheung ST, Lai CL, Liu CL, Ng IO, Yuen MF, et al. Liver transplantation in Asian patients with chronic hepatitis B using lamivudine prophylaxis. Ann Surg 2001;233:276-281. doi: 10.1097/00000658-200102000-00018.

[67] Park SJ, Paik SW, Choi MS, Lee JH, Koh KC, Kim SJ, et al. Is lamivudine with 1-week $\mathrm{HBlg}$ as effective as long-term high-dose $\mathrm{HBlg}$ in $\mathrm{HBV}$ prophylaxis after liver transplantation? Transplant Proc 2002;34:1252-1254. doi: 10. 1016/S0041-1345(02)02637-4.

[68] Roche B, Samuel D. Prevention of hepatitis B virus reinfection in liver transplant recipients. Intervirology 2014;57:196-201. doi: 10.1159/000360944.

[69] Choudhary NS, Saraf N, Saigal S, Mohanka R, Rastogi A, Goja S, et al. Lowdose short-term hepatitis $B$ immunoglobulin with high genetic barrier antivirals: the ideal post-transplant hepatitis B virus prophylaxis? Transpl Infect Dis 2015;17:329-333. doi: 10.1111/tid.12369.

[70] Roche B, Feray C, Gigou M, Roque-Afonso AM, Arulnaden JL, Delvart V, et al. HBV DNA persistence 10 years after liver transplantation despite successful anti-HBs passive immunoprophylaxis. Hepatology 2003;38:86-95. doi: 10. 1053/jhep.2003.50294.

[71] Lenci I, Tisone G, Di Paolo D, Marcuccilli F, Tariciotti L, Ciotti M, et al. Safety of complete and sustained prophylaxis withdrawal in patients livertransplanted for HBV-related cirrhosis at low risk of HBV recurrence. J Hepatol 2011;55:587-593. doi: 10.1016/j.jhep.2010.12.036.

[72] Sanchez-Fueyo A, Rimola A, Grande L, Costa J, Mas A, Navasa M, et al. Hepatitis $B$ immunoglobulin discontinuation followed by hepatitis $B$ virus vaccination: a new strategy in the prophylaxis of hepatitis $B$ virus recurrence after liver transplantation. Hepatology 2000;31:496-501. doi: 10. 1002/hep.510310233.

[73] Bienzle U, Gunther M, Neuhaus R, Vandepapeliere P, Vollmar J, Lun A, et al. Immunization with an adjuvant hepatitis $B$ vaccine after liver transplantation for hepatitis B-related disease. Hepatology 2003;38:811-819. doi: 10. 1002/hep.1840380407.

[74] Angelico M, Di Paolo D, Trinito MO, Petrolati A, Araco A, Zazza S, et al. Failure of a reinforced triple course of hepatitis $B$ vaccination in patients transplanted for HBV-related cirrhosis. Hepatology 2002;35:176-181. doi: 10. 1053/jhep.2002.30278.

[75] Weber NK, Forman LM, Trotter JF. HBIg discontinuation with maintenance oral anti-viral therapy and HBV vaccination in liver transplant recipients. Dig Dis Sci 2010;55:505-509. doi: 10.1007/s10620-009-0999-6.

[76] Karasu Z, Ozacar T, Akarca U, Ersoz G, Erensoy S, Gunsar F, et al. HBV vaccination in liver transplant recipients: not an effective strategy in the prophylaxis of HBV recurrence. J Viral Hepat 2005;12:212-215. doi: 10. 1111/j.1365-2893.2005.00585.x

[77] Rosenau J, Hooman N, Hadem J, Rifai K, Bahr MJ, Philipp G, et al. Failure of hepatitis $B$ vaccination with conventional HBsAg vaccine in patients with continuous HBIG prophylaxis after liver transplantation. Liver Transpl 2007;13:367-373. doi: 10.1002/lt.21003.

[78] Starkel P, Stoffel M, Lerut J, Horsmans Y. Response to an experimental HBV vaccine permits withdrawal of HBIg prophylaxis in fulminant and selected chronic HBV-infected liver graft recipients. Liver Transpl 2005;11:12281234. doi: $10.1002 /$ It.20464. 
[79] Wursthorn $\mathrm{K}$, Wedemeyer H, Manns MP. Managing HBV in patients with impaired immunity. Gut 2010;59:1430-1445. doi: 10.1136/gut.2009. 195834.

[80] Schumann A, Lindemann M, Valentin-Gamazo C, Lu M, Elmaagacli A, Dahmen $\mathrm{U}$, et al. Adoptive immune transfer of hepatitis $B$ virus specific immunity from immunized living liver donors to liver recipients. Transplantation 2009;87:103-111. doi: 10.1097/TP.0b013e31818bfc85.

[81] Luo Y, Lo CM, Cheung CK, Lau GK, Fan ST, Wong J. Identification of hepatitis $B$ virus-specific lymphocytes in human liver grafts from HBV-immune donors. Liver Transpl 2007;13:71-79. doi: 10.1002/It.20887.

[82] Gunther M, Neuhaus R, Bauer T, Jilg W, Holtz JA, Bienzle U, et al. Immunization with an adjuvant hepatitis $B$ vaccine in liver transplant recipients: antibody decline and booster vaccination with conventional vaccine. Liver Transpl 2006;12:316-319.

[83] Di Paolo D, Lenci I, Cerocchi C, Tariciotti L, Monaco A, Brega A, et al. One-year vaccination against hepatitis $B$ virus with a MPL-vaccine in live transplant patients for HBV-related cirrhosis. Transpl Int 2010;23:11051112. doi: 10.1111/j.1432-2277.2010.01104.x.

[84] Cholongitas E, Papatheodoridis GV. Review of the pharmacological management of hepatitis B viral infection before and after liver transplantation. World J Gastroenterol 2013;19:9189-9197. doi: 10.3748/wjg.v19.i48.9189.

[85] Cholongitas E, Papatheodoridis GV, Burroughs AK. Liver grafts from antihepatitis B core positive donors: a systematic review. J Hepatol 2010;52: 272-279. doi: 10.1016/j.jhep.2009.11.009.

[86] Rodriguez-Frias F, Buti M, Jardi R, Vargas V, Quer J, Cotrina M, et al. Genetic alterations in the $S$ gene of hepatitis $B$ virus in patients with acute hepatitis B, chronic hepatitis B and hepatitis B liver cirrhosis before and after liver transplantation. Liver 1999;19:177-182. doi: 10.1111/j.14783231.1999.tb00032.x.

[87] Ueda Y, Marusawa H, Egawa H, Okamoto S, Ogura Y, Oike F, et al. De novo activation of HBV with escape mutations from hepatitis B surface antibody after living donor liver transplantation. Antivir Ther 2011;16:479-487. doi: 10.3851/IMP1771.

[88] Buti M, Tabernero D, Mas A, Homs M, Prieto M, Rodriguez-Frias F, et al. Hepatitis B virus quasispecies evolution after liver transplantation in patients under long-term lamivudine prophylaxis with or without hepatitis B immune globulin. Transpl Infect Dis 2015;17:208-220. doi: 10.1111/tid. 12360.

[89] Terasaka $T$, Ueta E, Ebara H, Waseda $\mathrm{K}$, Hanayama $\mathrm{Y}$, Takaki A, et al. Longterm observation of osteomalacia caused by adefovir-induced Fanconi's syndrome. Acta Med Okayama 2014;68:53-56.

[90] Tamori A, Enomoto M, Kobayashi S, Iwai S, Morikawa H, Sakaguchi H, et al. Add-on combination therapy with adefovir dipivoxil induces renal impairment in patients with lamivudine-refractory hepatitis B virus. J Viral Hepat 2010;17:123-129. doi: 10.1111/j.1365-2893.2009.01160.x.

[91] Cai D, Mills C, Yu W, Yan R, Aldrich CE, Saputelli JR, et al. Identification of disubstituted sulfonamide compounds as specific inhibitors of hepatitis $B$ virus covalently closed circular DNA formation. Antimicrob Agents Chemother 2012;56:4277-4288. doi: 10.1128/AAC.00473-12.

[92] Wooddell CI, Rozema DB, Hossbach M, John M, Hamilton HL, Chu Q, et al. Hepatocyte-targeted RNAi therapeutics for the treatment of chronic hepatitis B virus infection. Mol Ther 2013;21:973-985. doi: 10.1038/mt.2013. 31.

[93] Petersen J, Dandri M, Mier W, Lütgehetmann M, Volz T, von Weizsäcker F, et al. Prevention of hepatitis $B$ virus infection in vivo by entry inhibitors derived from the large envelope protein. Nat Biotechnol 2008;26:335341. doi: 10.1038/nbt1389.

[94] Volz T, Allweiss L, Ben MBarek M, Warlich M, Lohse AW, Pollok JM, et al. The entry inhibitor Myrcludex- $B$ efficiently blocks intrahepatic virus spreading in humanized mice previously infected with hepatitis B virus. J Hepatol 2013; 58:861-867. doi: 10.1016/j.jhep.2012.12.008.

[95] Al-Mahtab M, Bazinet M, Vaillant A. Establishment of a potent anti-HBsAg response and durable immunological control of viremia with short term immunotherapy after REP 9AC-induced HBsAg seroclearance in chronic HBV infection (Internet). J Hepatol 2013;58:S316. doi: 10.1016/S01688278(13)60778-3.
[96] Ilan Y, Nagler A, Adler R, Tur-Kaspa R, Slavin S, Shouval D, et al. Ablation of persistent hepatitis $B$ by bone marrow transplantation from a hepatitis B-immune donor. Gastroenterology 1993;104:1818-1821.

[97] Couillin I, Pol S, Mancini M, Driss F, Bréchot C, Tiollais $P$, et al. Specific vaccine therapy in chronic hepatitis $B$ : induction of $T$ cell proliferative responses specific for envelope antigens. J Infect Dis 1999;180:15-26. doi: $10.1086 / 314828$.

[98] Hong SH, Cho O, Kim K, Shin HJ, Kotenko SV, Park S, et al. Effect of interferon-lambda on replication of hepatitis $B$ virus in human hepatoma cells. Virus Res 2007;126:245-249. doi: 10.1016/j.virusres.2007.03.006.

[99] Nakagawa S, Hirata $Y$, Kameyama T, Tokunaga $Y$, Nishito $Y$, Hirabayashi $K$, et al. Targeted induction of interferon- $\lambda$ in humanized chimeric mouse liver abrogates hepatotropic virus infection. PLoS One 2013;8:e59611. doi: 10. 1371/journal.pone.0059611.

[100] Chan H, Ahn S, Chang T, Peng C, Wong D, Coffin C, et al. Peginterferon Lambda for the Treatment of HBeAg-Positive Chronic Hepatitis B: A Phase 2B Comparison with Peginterferon Alfa. APASL Liver Week 2013; Singapore, June 6-10, 2013.

[101] Zeuzem S, Arora S, Bacon B, Box T, Charlton M, Diago M, et al. Peginterferon Lambda-1a (lambda) compared to peginterferonalfa-2a (alfa) in treatment-naïve patients with HCV genotypes (G) 2 or 3: First SVR24 results from EMERGE phase IIB. J Hepatol 2012;56:S5-S6. doi: 10. 1016/S0168-8278(12)60024-5.

[102] Lanford RE, Guerra B, Chavez D, Giavedoni L, Hodara VL, Brasky KM, et al. GS-9620, an oral agonist of Toll-like receptor-7, induces prolonged suppression of hepatitis B virus in chronically infected chimpanzees. Gastroenterology 2013;144:1508-1517, doi: 1517.e1-e10nt.

[103] Seehofer D, Rayes N, Naumann U, Neuhaus R, Müller AR, Tullies SG, et al. Preoperative antiviral treatment and postoperative prophylaxis in HBV-DNA positive patients undergoing liver transplantation. Transplantation 2001; 72:1381-1385. doi: 10.1097/00007890-200110270-00008.

[104] Steinmuller T, Seehofer D, Rayes N, Müller AR, Settmacher U, Jonas S, et al. Increasing applicability of liver transplantation for patients with hepatitis B-related liver disease. Hepatology 2002;35:1528-1535. doi: 10.1053/ jhep.2002.33681.

[105] Ferreti G, Merli M, GinanniCorradini S, Callejon V, Tanzilli P, Masini A, et al. Low-dose hepatitis $B$ immune globulin and lamivudine for long-term prophylaxis of hepatitis B recurrence after liver transplantation. Transplant Proc 2004;36:535-538. doi: 10.1016/j.transproceed.2004.02.025.

[106] Karademir S, Astarcioglu H, Akarsu M, Ozkardesler S, Ozzeybek D, Sayiner $A$, et al. Prophylactic use of low-dose, on-demand intramuscular hepatitis B immune globulin and lamivudine after liver transplant. Transplant Proc 2006;38:579-583. doi: 10.1016/j.transproceed.2005.12.063.

[107] Wong SN, Chu C], Wai CT, Howell T, Moore C, Fontana R], et al. Low risk of hepatitis B virus recurrence after withdrawal of long-term hepatitis B immunoglobulin in patients receiving maintenance nucleos(t)ide analogue therapy. Liver Transpl 2007;13:374-381. doi: 10.1002/It.21041.

[108] Yuefeng M, Weili F, Wenxiang T, Ligang X, Guiling L, Hongwei G, et al. Longterm outcome of patients with lamivudine after early cessation of hepatitis B immunoglobulin for prevention of recurrent hepatitis B following liver transplantation. Clin Transplant 2010;25:517-522. doi: 10.1111/j.13990012.2010.01290.x.

[109] Saab S, Desai S, Tsaoi D, Durazo F, Han S, McClune A, et al. Posttransplantation hepatitis B prophylaxis with combination oral nucleoside and nucleotide analog therapy. Am J Transplant 2011;11:511-517. doi: 10.1111/j. 1600-6143.2010.03416.x.

[110] Nath DS, Kalis A, Nelson S, Payne WD, Lake JR, Humar A, et al. Hepatitis B prophylaxis post-liver transplant without maintenance hepatitis $B$ immunoglobulin therapy. Clin Transplant 2006;20:206-210. doi: 10.1111/j.13990012.2005.00467.x.

[111] Neff GW, Kemmer N, Kaiser TE, Zacharias VC, Alonzo M, Thomas M, et al. Combination therapy in liver transplant recipients with hepatitis $B$ virus without hepatitis B immune globulin. Dig Dis Sci 2007;52:2497-2500. doi: $10.1007 /$ s10620-006-9658-3. 